Utah State University

DigitalCommons@USU

Library Faculty \& Staff Publications

Libraries

$5-2-2018$

\title{
Tools for Troubleshooting: Which Ones and What For
}

Robert Heaton

Utah State University

Follow this and additional works at: https://digitalcommons.usu.edu/lib_pubs

Part of the Library and Information Science Commons

\section{Recommended Citation}

Robert Heaton (2018) Tools for troubleshooting: Which ones and what for, Journal of Electronic Resources Librarianship, 30:1, 9-26, DOI: 10.1080/1941126X.2018.1443903

This Article is brought to you for free and open access by the Libraries at DigitalCommons@USU. It has been accepted for inclusion in Library Faculty \& Staff Publications by an authorized administrator of DigitalCommons@USU. For more information, please contact digitalcommons@usu.edu.

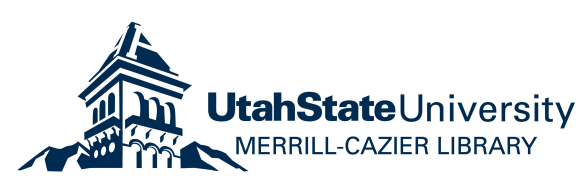




\begin{abstract}
A small group of midsize land-grant institutions in the western United States responded to a survey on what tools they used for troubleshooting, what activities they accomplished using the tools, and who performed their troubleshooting. Most respondents use subscription-manager administration tools, email programs, electronic resource management systems, and ticket trackers, but many other software programs are each used at a small number of institutions. Most tools support multiple troubleshooting activities, and most troubleshooting activities are supported by multiple tools. Most libraries have slightly more paraprofessionals than faculty with some troubleshooting responsibility, but nearly all have at least one of each.
\end{abstract}

Keywords: troubleshooting, tools, software, staffing, electronic resources, access

Author's Note: Robert Heaton is Collection Management Librarian at the Merrill-Cazier Library, Utah State University, 3000 Old Main Hill, Logan UT 84322-3000. Email:

robert.heaton@usu.edu. ORCiD: 0000-0001-9067-1534.

Received: July 20, 2017

Accepted: October 9, 2017

This is the accepted manuscript following peer review. This article's version of record is available from Taylor \& Francis at https://doi.org/10.1080/1941126X.2018.1443903. 


\section{Tools for Troubleshooting: Which Ones and What For}

Libraries spend millions of dollars each year on electronic resources, but if these resources are not fully available to users, then that money is spent in vain. Electronic resource managers work hard to ensure the highest possible "uptime" for all their online resources, and a growing body of literature describes how library personnel go about doing the work of troubleshooting. An unprecedented range of software tools from library vendors and technology companies can facilitate the various tasks related to troubleshooting. This small-scale study of the author's peer institutions addresses the following research questions:

Q1. What tools are used for troubleshooting?

Q2. What troubleshooting activities are the tools used for?

Q3. What staffing arrangements support libraries' troubleshooting activities?

\section{Literature Review}

Tools for productivity and communication proliferate online. Their pricing, features, and ease of use vary. The literature suggests that many of these have made their way into library operations, including the specific tools ServiceNow (Carter \& Traill, 2017), Trello, Zapier, IFTTT, Footprints (Finch, 2014), JIRA, Drupal, Basecamp (Wilson, 2011), BugZilla (Browning, 2015), LibGuides, IBM Business Process Manager (Rathmel, Mobley, Pennington, \& Chandler, 2015), and Microsoft SharePoint (Ennis \& Tims, 2012), as well as generic tool categories such as bug-reporting (Rupp \& Mobley, 2007) and ticket-tracking tools (Borchert, 2006), virtual chat (Resnick \& Clark, 2009), blogs (Pan, Bradbeer, \& Jurries, 2011), shared documents (Carter \& Traill, 2017), wikis, electronic resource management systems (ERMS), integrated library systems (ILS), intranets, spreadsheets, web forms, and shared email accounts (Rathmel et al., 2015). The abundance of software applications in use in libraries according to these publications 
confirms that libraries may benefit from sharing how they chose the tools that they use and whether they are happy with them.

Researchers studying troubleshooting practices are concerned not only with the tools themselves but also with the tasks achieved using those tools. At a high level, troubleshooting falls under the TERMS stage of "Ongoing Evaluation and Access" (Emery \& Stone, n.d.). The older Digital Library Federation E-Resources Management report (Jewell et al., 2004) is referenced in Rathmel et al. (2015) to situate troubleshooting within the general category of “resource administration and management" (p. 89), but Rathmel et al. add considerable detail over the course of discussion: Tools "allow for staff and users to report problems via either a web form or by email" (p. 97); staff can then "monitor and ... follow the progression of a problem report to its resolution" (p. 95), including "keeping track of problem reports, managing the flow of work and communication, and creating a knowledge base of issues previously reported and resolved" (p. 89). Powerful uses of some tools included the ability to "communicate directly with end users" (p. 100) as well as "statistics reporting and the [ability] to assign and track problem reports” (p. 95). Carter and Traill (2017) suggest, “All tracking systems can provide statistics with a bit of work" (p. 5), but not all troubleshooting tasks merit the sustained hacking required to do so. When troubleshooting personnel consider adopting new software, they are interested in how that software is (or could be) used. Therefore, any study of the tools used in the complex art of troubleshooting should account for specific use cases and the ways that those tools simplify, automate, or facilitate concrete tasks.

The literature devotes some attention to the role of staffing as a crucial part of troubleshooting. Samples and Healy (2014) go so far as to assert that libraries' troubleshooting "solutions and successes are all related to staffing" (p. 109). Carter and Traill (2017) note that 
implementing a web-scale discovery system brings with it "a larger number of potential failure points among the variety of interoperating systems" and therefore requires reconfiguring workflows and staff configurations around new troubleshooting challenges (pp. 1-2). They also recommended "[i]ncreasing the skills and number of individuals [throughout the library] who can contribute to troubleshooting activities" (p. 6). Rathmel et al. (2015) found that technical services was the most likely organizational home for troubleshooting personnel, followed by public services and library IT (p. 98). Resnick and Clark (2009), in contrast, claim, “The traditional library divisions ... are no longer helpful in enabling consistent and reliable access to electronic resources." Instead, "access [is] an integrated process that is part of everyone's job" (p. 370).

This study collects information on the personnel dedicated to troubleshooting in order to confirm the literature's findings so that other libraries can evaluate their staffing practices in that light. (Note that this article uses the term "personnel" instead of "staff" to designate library employees in general in order to avoid confusion with the common distinction between "faculty" and "staff" job levels. The term "staffing" is sometimes used, though, because it does not carry the same risk. These distinctions in wording were not made in the survey itself.)

\section{Method}

This study was conducted in the form of an online survey using Qualtrics, and counts and cross-tabulations were generated using Microsoft Excel 2013, as were each of the figures and tables that display response data. (The survey instrument is included as an appendix to this article.) The survey was distributed to the ten universities that the Board of Regents at Utah State University (USU) has chosen as USU's peer institutions, shown with general comparison data as Table 1. This population was chosen for the obvious advantage of bringing the survey's findings 
back to the author's institution, where they were likely to be immediately applicable. On the other hand, according to various measures such as enrollment counts, library expenditures, and the number of library employees, the group varies considerably, and therefore a broad readership will identify with at least some characteristics of some of the institutions (see Table 1).

Table 1: Institutional Data for Study Population

\begin{tabular}{|c|c|c|c|c|}
\hline \multirow{2}{*}{ Institution } & \multirow{2}{*}{$\begin{array}{l}\text { Students } \\
\text { (FTE) }\end{array}$} & \multicolumn{3}{|c|}{ Library Data } \\
\hline & & $\begin{array}{r}\text { Personnel } \\
\text { (FTE) }\end{array}$ & $\begin{array}{r}\text { Expenditures } \\
(\text { USD) }\end{array}$ & Circulation \\
\hline Colorado State University & 25,903 & 192 & - & 111,527 \\
\hline Washington State University & 24,712 & 140 & $14,136,589$ & 211,086 \\
\hline Oregon State University & 22,544 & 114 & $9,627,311$ & 237,507 \\
\hline University of Nebraska-Lincoln & 22,342 & 174 & $16,213,094$ & 158,234 \\
\hline Kansas State University & 21,235 & 128 & $14,676,605$ & 112,752 \\
\hline Utah State University & 20,017 & 86 & $8,820,015$ & 120,717 \\
\hline University of Nevada-Reno & 15,145 & 117 & $9,690,193$ & 162,906 \\
\hline New Mexico State University & 14,984 & 102 & $7,180,791$ & 59,148 \\
\hline Montana State University & 11,779 & 61 & $7,922,366$ & 39,059 \\
\hline University of Wyoming & 11,100 & 92 & $12,632,877$ & 199,990 \\
\hline University of Idaho & 10,968 & 65 & $7,291,039$ & 89,755 \\
\hline Comparison group median & 18,190 & 115 & $11,161,535$ & 135,493 \\
\hline
\end{tabular}

Note. FTE = full-time equivalent. No expenditure data were reported by Colorado State University. Data from "Compare academic libraries," by the National Center for Educational Statistics (2013), https://nces.ed.gov/surveys/libraries/Compare/Default.aspx.

Responses were gathered during the 5-week period following the survey's distribution on April 15, 2016. Eleven responses were received, but after four blank surveys and that of one institution whose employees responded twice were removed, six usable responses remained. (The usable responses included two that were not fully completed but were still useful insofar as they were completed. The number of respondents to a particular question is listed in each figure and varies among 4, 5, and 6.) In the case of the partially duplicated survey, the author manually 
combined the responses to ensure that nothing was lost from either instance of the survey while maintaining the integrity of the count of institutions. The author's own completed survey was among those received so that local practices could be included among the peer-group data. In total, the six completed surveys represented a response rate of 55\%. Responses were received from institutions at the bottom, middle, and top of the various quantitative measures shown in Table 1, and responses were therefore considered generally representative of those of the population. Still, with such a small sample, the findings cannot be generalized even to this small population, so no particular statistical tests were applied to the data. Instead, these findings are intended as an initial probe to refine questions that may be raised in future studies of e-resource troubleshooting.

Following an introductory statement, the survey continues with sections on troubleshooting personnel, tools used, activities accomplished using the tools, personnel's satisfaction with each tool, the process of selecting each tool for implementation, and respondent demographic information. Factors correlated with personnel satisfaction with tools are not reported here but will be published elsewhere.

As the author formulated the survey questions, the idea of a drop-down menu populated with all potential software tools was considered, but the 67 tools identified made such an arrangement unwieldy. In addition, there was no way to know if the study population was more likely to have branched into little-known tools that were not on that list or to have limited themselves to the most common software suites, such as those of Google and Microsoft. In addition to the sheer volume of possible tools, overlapping categories to which each could belong presented a further complication. Rathmel et al. (2015) correctly assert, "As tools continue to evolve, it becomes more difficult to separate the category to which each tool belongs" (p. 97). 
As a compromise intended to sidestep this categorization issue while capturing a list of the specific tools used, the author organized possible responses into 14 categories—-such as "An electronic resources management system," "A subscription-manager admin tool," and "An email program"- but allowed respondents to fill in the tool names themselves. This meant that eresource personnel could consider Outlook an email program as well as a calendar program, or personnel from different libraries could categorize Trello as either a ticket tracker or projectmanagement program. Figure 1 shows the general tool categories as presented in the survey, and Table 2 shows the specific tools that were entered as free responses and during data analysis standardized to those listed.

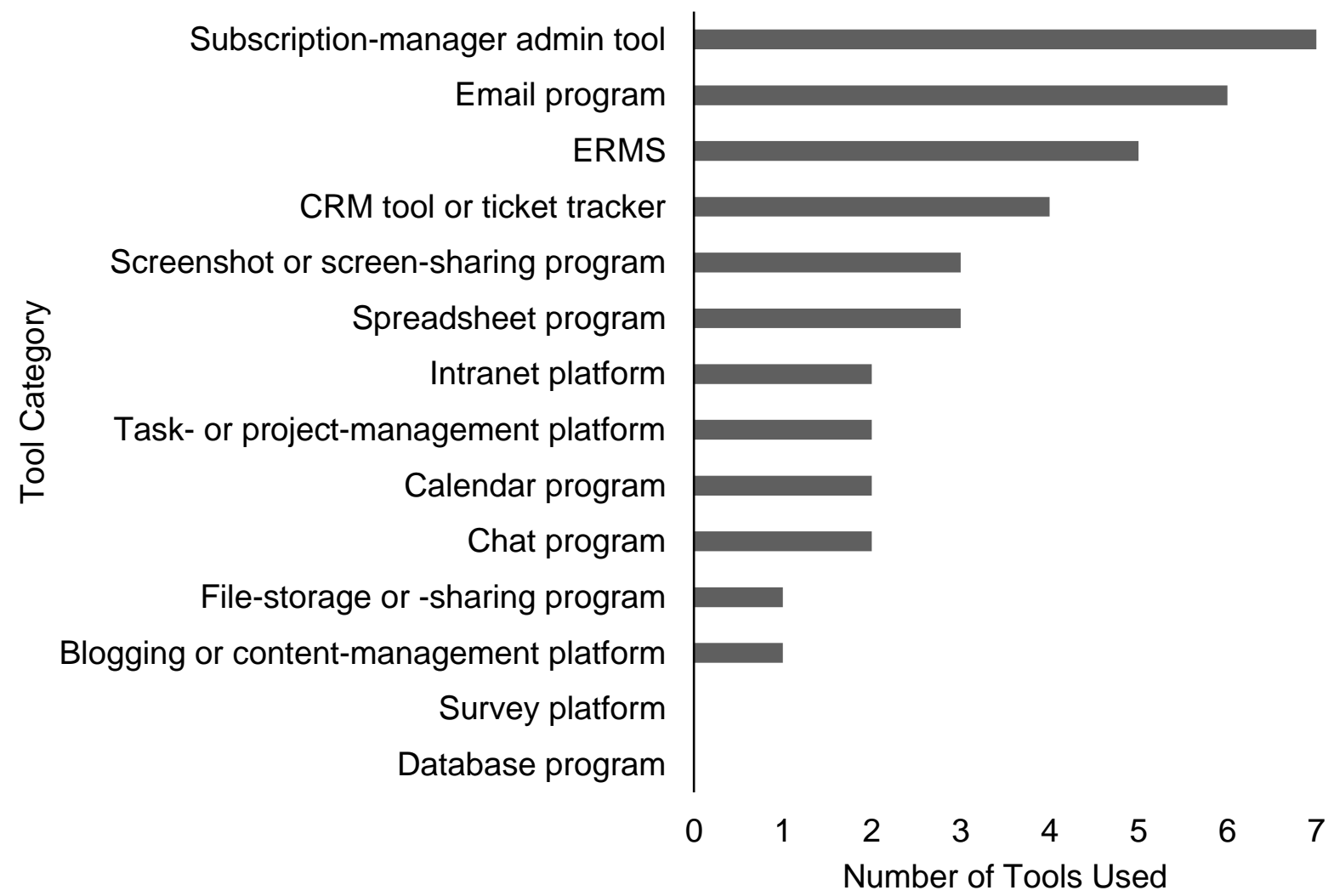

Figure 1: Number of tools used at responding libraries for electronic-resource troubleshooting, listed by category. $n=5$. Categories were predefined in the survey. Some respondents reported using multiple tools in a category. 
Similar to how tool categories were presented in the survey, three general areas of troubleshooting activity were predefined with accompanying explanatory examples:

- "Gather information to understand and replicate the issue (e.g., receive issue reports from users or librarians, review past issues for relevant clues, replicate the issue on staff computers)

- "Communicate issue status to users (e.g., general notices on a blog or website, direct email to the individual who reported an issue, in-house memos to prepare staff for user complaints)

- "Coordinate tasks among troubleshooting team and other library staff (e.g., assign tasks to troubleshooting staff, schedule tasks for later follow-up, view task status in real time)" (See Appendix, Q11)

As with tool categories, respondents may have varied in how they interpreted the above activity areas as an effect of the differences in how troubleshooting is handled at their respective institutions.

In order to simplify the survey, the author chose not to prescribe an explicit definition of "troubleshooting." The term is generally associated with those actions taken in response to reported issues, but some libraries may have also included as troubleshooting activities proactive behaviors such as checking links to electronic resources. This potential difference in interpreting the term may have inflated some libraries' counts of the personnel and hours dedicated to troubleshooting, as shown in Figures 4 and 5. 


\section{Results}

\section{Tools}

Figure 1 shows the number of tools that respondents reported using in direct support of their troubleshooting activities. Note that the categories were included in the survey questions rather than generated by respondents. Also note that in a small number of cases, personnel at the same library used more than one tool for the same activity; the chart reflects the total number of tools listed as used in that tool category.

[insert Figure 1]

No one should be surprised to see that email was among the most-used tools for troubleshooting. All respondents used an ERMS and a subscription-manager admin tool, and more than half used some kind of customer-relations-management (CRM) or ticket-tracking tool. Only three tool categories received multiple responses from some libraries: subscription managers (two libraries used both EBSCONet and Harrassowitz's OttoSerials), email (one library used both Outlook and Gmail), and spreadsheets (one library used both Excel and Google Sheets).

Not all tools saw such widespread use. Besides email, ERMS, subscription managers, CRMs, and spreadsheets, none of the tool categories was used by more than two libraries (or $40 \%$ of respondents), suggesting some variety in how troubleshooting personnel structure the activities involved. The author was surprised that no respondent used a survey platform, because it is extremely common for libraries to embed survey forms into public-facing pages such as the dozens returned on a web search for "report an e-resource problem" (without quotation marks). It is possible that such a form is not maintained at these institutions, the respondent was not aware of it, the library's page is powered by a web form instead of survey software, or they did not 
make the connection between the tool category and their implementation of it. Finally, database programs also were not used for troubleshooting at any responding libraries. Databases could have many uses, including logging troubleshooting tickets or populating a public web page with outage information, but setting up a database for such a purpose requires some specialized expertise. Database-driven tools may also have been included in other categories.

Along with the categories of tools used for troubleshooting, this study explored the particular tools used. Table 2 shows all the specific tools that respondents use for troubleshooting at their libraries. The tool category with the biggest variety of individual products used was ERMS, with four different products: two Alma libraries and one each using Sierra, Millennium, and 360 Resource Manager. The next most varied categories were subscription manager and screenshot or screen-sharing program, with three tools each: EBSCONet, OttoSerials, and CoxNet and Jing, SnagIt, and HyperSnap, respectively. No other tool category had more than two options in use among responding libraries. 
Table 2: Number of Institutions Using Each Tool for Troubleshooting

\begin{tabular}{|c|c|}
\hline Tool & Institutions ${ }^{a}$ \\
\hline \multicolumn{2}{|l|}{ Subscription-manager admin tool } \\
\hline EBSCONet & 4 \\
\hline OttoSerials (Harrassowitz) & 2 \\
\hline CoxNet (W.T. Cox) & 1 \\
\hline \multicolumn{2}{|l|}{ Email program } \\
\hline Outlook (Microsoft) & 5 \\
\hline Gmail (Google) & 1 \\
\hline \multicolumn{2}{|l|}{ Electronic resources management system (ERMS) } \\
\hline Alma (Ex Libris) & 2 \\
\hline Sierra ERM (Innovative) & 1 \\
\hline Millennium ERM (Innovative) & 1 \\
\hline 360 Resource Manager (Serials Solutions) & 1 \\
\hline \multicolumn{2}{|l|}{ Customer-relations-management tool or ticket tracker } \\
\hline LibAnswers (Springshare) & 3 \\
\hline Web Help Desk (SolarWinds) & 1 \\
\hline \multicolumn{2}{|l|}{ Screenshot or screen-sharing program } \\
\hline Jing (TechSmith) & 1 \\
\hline Snaglt (TechSmith) & 1 \\
\hline HyperSnap (Hyperionics) & 1 \\
\hline \multicolumn{2}{|l|}{ Spreadsheet program } \\
\hline Excel (Microsoft) & 2 \\
\hline Google Sheets & 1 \\
\hline \multicolumn{2}{|l|}{ Intranet platform } \\
\hline SharePoint (Microsoft) & 1 \\
\hline Drupal & 1 \\
\hline \multicolumn{2}{|l|}{ Task- or project-management platform } \\
\hline Trello & 1 \\
\hline Outlook (Microsoft) & 1 \\
\hline \multicolumn{2}{|l|}{ Calendar program } \\
\hline Outlook (Microsoft) & 2 \\
\hline \multicolumn{2}{|l|}{ Chat program } \\
\hline Lync (Microsoft) & 1 \\
\hline LibraryH3lp (Nub Games) & 1 \\
\hline \multicolumn{2}{|l|}{ File-storage or -sharing program } \\
\hline Google Drive & 1 \\
\hline \multicolumn{2}{|l|}{ Blogging or content-management platform } \\
\hline WordPress & 1 \\
\hline Survey platform & \\
\hline- & - \\
\hline Database program & \\
\hline
\end{tabular}

Note. No respondents reported using a survey platform or database program in support of their troubleshooting activities.

a $n=5$. 
The author had only passing familiarity with a number of the tools, and two-Web Help Desk and HyperSnap — were completely new. As a contrasting example, in response to the question "Does your institution use troubleshooting tools not listed above?," one respondent entered "Telephone." No further data were gathered in relation to this free response; rather, the option was given so that suggestions might be included in future research. It is hoped that this article opens up new possibilities to troubleshooting personnel that were not familiar with the tools available in each functional category but also inspires them not to take tried-and-true tools for granted.

In addition to the tool categories, the survey presented respondents with three overarching areas of troubleshooting activities to which each tool might be applied. These areas were "Gather information to understand and replicate the issue," "Communicate issue status to users," and "Coordinate tasks among troubleshooting team and other library staff." Further context was given in the survey as articulated in the method section of this article.

Responses to the question "What troubleshooting activities are accomplished using each tool?" are compiled as Figure 2. The chart is organized such that the five tools at the top are those that some respondent used for each of the three activity areas, followed by the seven tools that were used for only two activity areas. Again, survey and database software were not used by any responding library. None of the tools accomplished only one activity. 


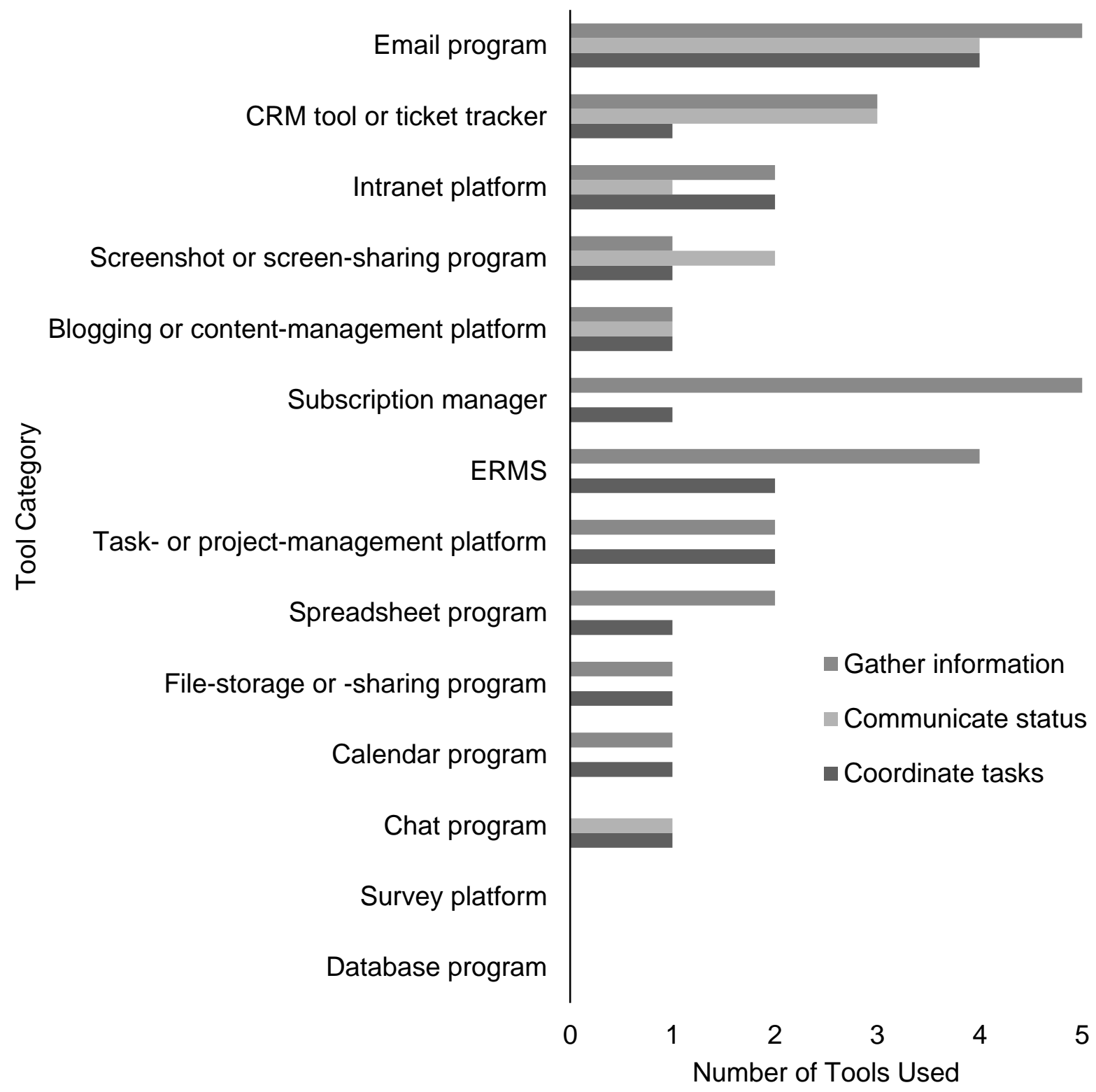

Figure 2: Number of tools used at responding libraries for each area of electronic-resource troubleshooting activity, listed by category. $n=5$. Tool categories are arranged first by number of activities to which a tool was applied and then by number of tools used. Tool categories were predefined in the survey. Activity areas were predefined in the survey as "Gather information to understand and replicate the issue," "Communicate issue status to users," and "Coordinate tasks among troubleshooting team and other library staff."

Many of the trends in the counts of tool categories used for each activity area are strictly logical. Neither calendar nor spreadsheet programs lend themselves well to sending the receiving 
specific communication about the status of a reported issue. Instead, calendars and spreadsheets are very well suited to scheduling tasks and analyzing data, which is how respondents reported using them.

However, there are incongruities as well. CRM tools or ticket trackers can work very well for centralizing the assignment of tasks to members of the troubleshooting team, but of the four libraries using this type of tool, only one (25\%) claims to use it for coordinating tasks in that way. One explanation for this apparent discrepancy is that some of these tools may also be considered a task-management or project-management platform, which was its own category. If respondents used a program only (or mostly) for one of these two functions, they may have listed it in the one place and not the other.

The fact that email is used in all three activities at almost all libraries reflects the reality that e-resource troubleshooting is largely an exercise in interpersonal communication. And because email programs are built around communication above all else, they are likely to remain critical to the work done by troubleshooting personnel. One library (20\%) rose above being tied to email for all three activities and relied on it only for the initial gathering of information from the person reporting the issue. Future researchers may find it interesting to learn in what activities troubleshooting personnel have replaced email, how they have done so, and with what degree of success.

Figure 2 highlights the relative versatility of tools in each category as well as the relative market penetration of tools in each area of troubleshooting activity. As a contrasting visualization of the tools used, Figure 3 shows how many tools were used in each of the three activity areas described above. This shifts the focus from the tool categories to the activities themselves and also shows the overall contrast among the number of tools each library uses. 
Note that the term "tool categories" is used throughout this section as the rough equivalent of the count of specific tools although some institutions used more than one tool in one or two tool categories.

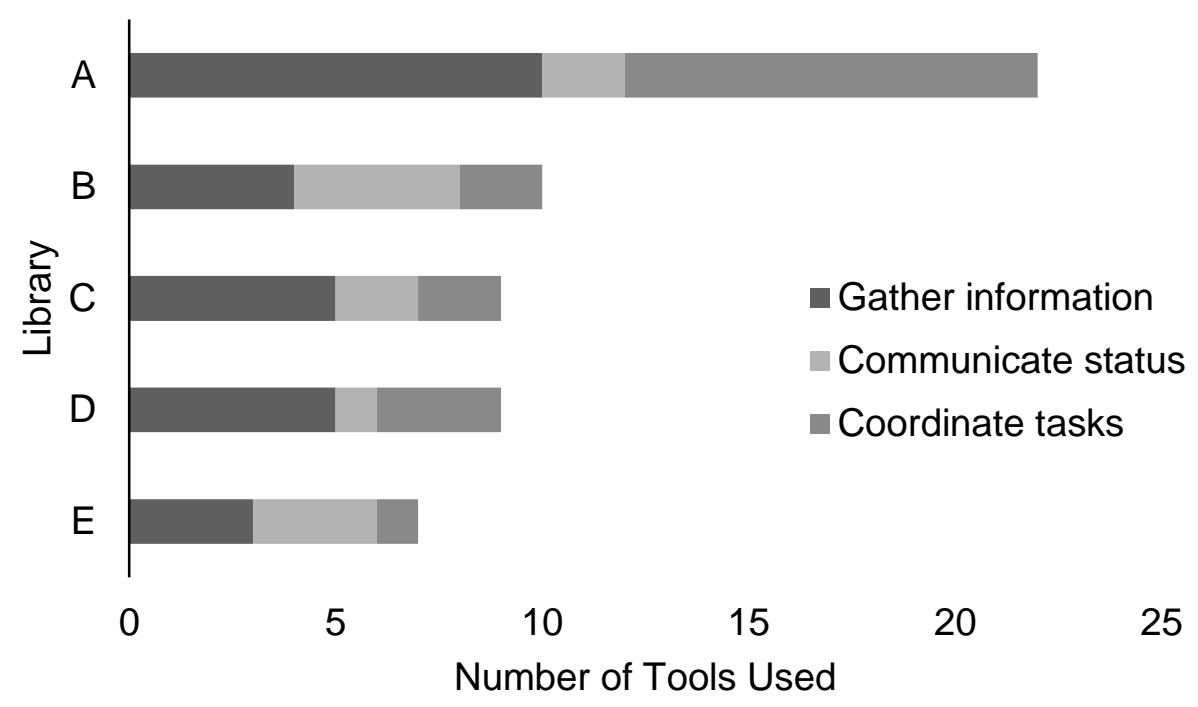

Figure 3: Number of tools used at responding libraries for each troubleshooting activity, listed by library. $n=5$. Activity areas were predefined in the survey as "Gather information to understand and replicate the issue," "Communicate issue status to users," and "Coordinate tasks among troubleshooting team and other library staff."

All responding libraries engaged in each activity to some degree. Library personnel applied as few as 7 and as many as 22 tool categories to the three activity areas. (The overall tool counts represent applications of a tool to an activity, so a tool may be counted as many as three times per library.) The most tool categories used for any activity area was 10 ; the fewest was 1 . On average, troubleshooting personnel used tools in 3.8 categories to carry out the various tasks associated with each activity area: Slightly more tools (5.4) were used to gather information about the reported issue than those (3.6) applied to coordinating troubleshooting tasks internally, with personnel drawing on the fewest categories (2.4) to communicate the issue status to users. 


\section{Staffing}

The survey asked for basic information on each individual with some troubleshooting responsibility. The data in Figures 4 and 5 were aggregated from those responses. The survey asked for "job level" and gave the suggestions of "faculty," "professional," and "paraprofessional" without any definitions or criteria to standardize responses. Because only one respondent listed "professional" as one of their library's designated job levels (alongside one paraprofessional), the professional staff member was included in the counts of faculty given in Figures 4 and 5. This is further justified by the considerable differences in faculty designations at different institutions (Walters, 2016), but future researchers might seek more information to clarify what is meant with each job-level option. Figure 4 reports the number of personnel with any troubleshooting responsibility, and Figure 5 reports the time those individuals spend on troubleshooting activities in an average week.

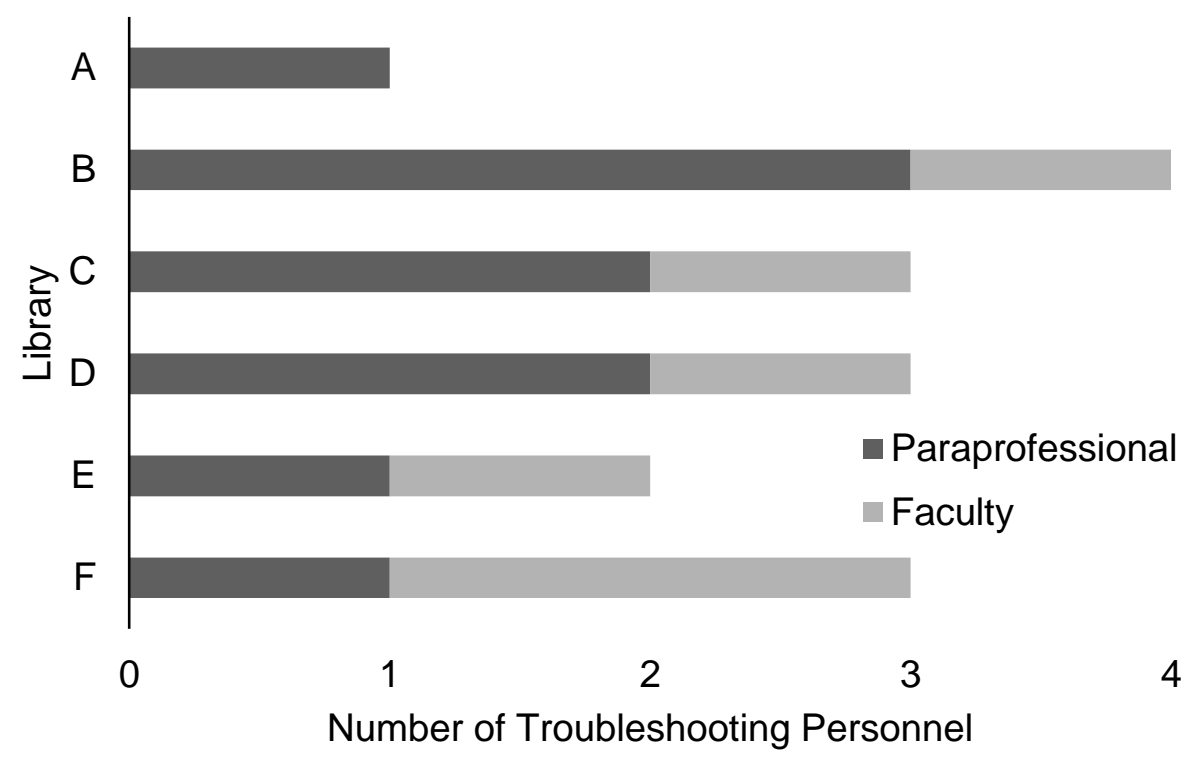

Figure 4: Number of employees responsible for troubleshooting at responding libraries, listed by library. $n=6$. Letter designations for each library are retained from Figure 3 for comparison. "Professional" and "Faculty" positions are conflated into a single Faculty level. 


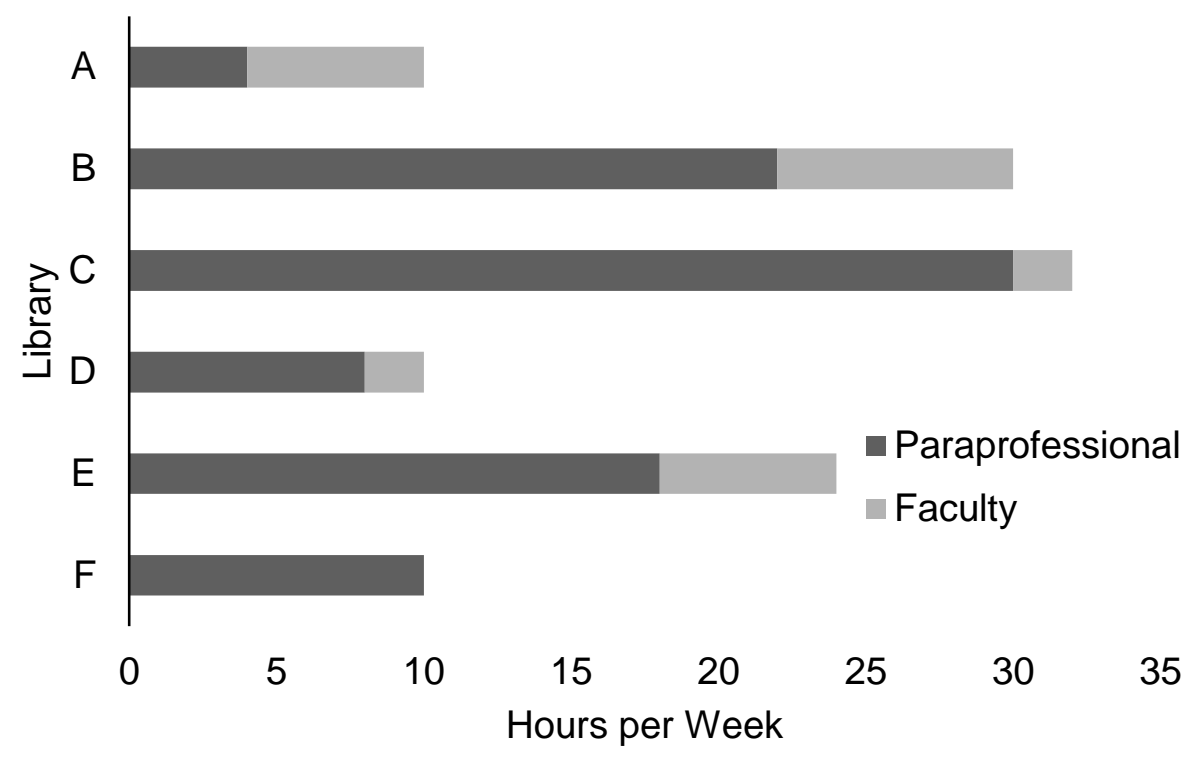

Figure 5: Average time dedicated to troubleshooting weekly at responding libraries, listed by library. $n=6$. Letter designations for each library are retained from Figures 3 and 4 for comparison.

These six libraries averaged about 1.6 paraprofessional staff and 1.2 faculty with responsibility for troubleshooting. Another way of expressing this is that the ratio of these arithmetic means is about 1.38: There are, on average, 1.38 paraprofessional staff for every 1 faculty position with some responsibility for troubleshooting. One library was the outlier in the balance of paraprofessional staff and faculty, with 2 faculty and only 1 paraprofessional position with troubleshooting responsibility. The fact that this library tied for the fewest hours per week dedicated to troubleshooting (as shown in Figure 5) may help explain that library's unique situation. Among respondents, total positions with some troubleshooting responsibility range from only 1 to as high as 4 , with most libraries falling somewhere in the middle. With a larger sample, these responses might conform to a normal distribution.

To help readers contextualize these numbers in terms of their own institutions, they are directed to the list of surveyed institutions in Table 1, in the method section, which shows that 
the population reflected in this study has a median enrollment of about 18,000 FTE, 115 total library personnel, and a total library budget of \$11 million. All are doctoral-granting institutions with a Carnegie classification of Research Extensive or, in one case, Research Intensive according to the designations in place at the time of the 2012 IPEDS survey.

The total employee counts are useful but incomplete without the numbers shown in Figure 5, which shows the relative weekly time commitment of paraprofessional and faculty positions to troubleshooting activities. Unless a troubleshooting team tracks these numbers in detail, these numbers are rather difficult to estimate and should be taken as rough approximations.

The total time dedicated to troubleshooting varied considerably by institution, from approximately 10 to 32 hours in the average week. The hours dedicated to troubleshooting per number of troubleshooting personnel similarly varied, from approximately 3.3 to 10.7 . However, no consistent correlation was shown between number of personnel and hours dedicated to troubleshooting. For example, Library B had the most personnel (four) and nearly the highest hours per week (30) while Library E, with half the personnel of Library B (two vs. four), dedicated only $20 \%$ fewer hours to troubleshooting (24 hours vs. 30). Meanwhile, Library A had only one employee, compared to three at Libraries D and F, but dedicated the same number of hours (10) as they did to troubleshooting. The handling of troubleshooting work by personnel level was more consistent: When a library employed both paraprofessional staff and faculty, the larger number of hours fell to paraprofessionals in all but one library. On average, as measured by work hours, around $79 \%$ of the troubleshooting work was handled by paraprofessional staff and the other $21 \%$ by faculty. 


\section{Discussion}

The implications of the above findings are discussed here as they relate to the research questions expressed in this article's introduction.

\section{Q1. What tools are used for troubleshooting?}

A key goal of any e-resources librarian is to apply technology and expertise in the most costeffective ways to improve the library's service to its users. For individual institutions to make informed decisions related to their technology, the most basic step is to know what tools are available to them. As a starting point in that effort, Figure 1 shows the troubleshooting tools used at the institutions studied.

The list itself is instructive, and troubleshooting staff may draw several conclusions from considering it in light of their local conditions. At a glance, one notices that the bulk of respondents' troubleshooting work is done by a small range of tools: email, ticket trackers, ERMS, subscription-agent interfaces, and spreadsheets. Most of these in turn come from a small range of providers, such as Microsoft, EBSCO, and Springshare. On the other hand, there is a pronounced "long tail" of tools, each used by only one responding library: This is the case for 17 of 23 tools (around 74\%), counting the individual tools across all tool categories. Surely data from a larger sample would begin to cluster into groups of institutions using the same tools; at the same time, such a data set could also make evident an even longer tail of lone users.

Centralized powerhouses in the market make it more likely that multiple institutions will adopt fewer products, but even though such tools are indeed popular, they are apparently insufficient for the tasks to which library personnel apply them. Software vendors that grasp users' motivations for adopting such a diversity of tools will be strongly positioned to respond to those needs, possibly much more efficiently than they do now. As an alternate path, library 
consortia might benefit from internal networks of expertise where members share information on selecting tools and support one another in using them. Further research is needed before conclusions can be drawn regarding this selection process, including whether library staff would benefit more from using fewer, more robust, tools or from using more, narrowly specialized, tools.

\section{Q2. What troubleshooting activities are the tools used for?}

The literature places troubleshooting into various defined stages of managing the e-resource lifecycle, but little has been written to categorize the activities that constitute troubleshooting. In the context of the three general areas of activity presented earlier in this article, two findings predominate. First, the number of tools used for a given activity varied widely among responding libraries. As mentioned above, one library used ten tools in each of two areas: to gather information about issues and to coordinate troubleshooting tasks among staff. In contrast, one library used only one tool to communicate the status of issues to users, and another library used only one tool to coordinate tasks internally. No standard practice has evolved regarding the quantity of tools that libraries apply to areas of activity. The second finding is that communicating issue status is the activity for which libraries used the fewest tools. As observed above, perhaps email simply meets this need, but this cannot be the full explanation: One outlier did not use email for this activity.

These findings are far from conclusive and suggest a need for continued research. Library personnel may apply a high quantity of tools to an area of troubleshooting activity either because of thoroughness or inefficiency. Using many tools may mean that library personnel are productively experimenting with emerging technologies, or it may mean that they do not effectively retire legacy tools. On the other hand, using only a few tools may reflect either high 
efficiency or unwillingness to try specialized tools for particular tasks. The high number of tools applied to troubleshooting could be taken as an indictment against the vendors of "integrated library systems" that do not fulfill the promise of integration; the lack of standard categories for troubleshooting tasks, combined with the range of tools and ways of implementing them, may instead place the blame on library personnel who have failed to communicate or even grasp the nature of their needs. A larger sample might also show that libraries with more employees or higher budgets are more likely to use more tools or adopt new ones more slowly (or the reverse).

Along with the survey results, this study's method for organizing troubleshooting activities raises many questions. The survey makes sweeping generalizations about the activities involved in troubleshooting. As an example, the area of "gathering information" could easily be broken down further into such personnel activities as these:

- receiving a call, chat, email, or in-person report of an issue;

- asking a series of questions to ensure understanding;

- replicating the issue (or attempting to replicate it), including on and off campus, in various browsers, and on various devices;

- referring to a knowledgebase of previous problem reports to identify a known solution;

- $\quad$ searching print and electronic records to verify a current subscription (or other justification of access);

- consulting with specialized personnel to understand potential problems related to interoperability between systems, user authentication, or timely invoice processing; and - documenting the information gathered at each of the above stages.

Future researchers can judge whether more is gained or lost through the simplification of this range of tasks into a broader area of activity. It may be noteworthy, however, to mention that no 
responses were given to the question "Does your institution engage in troubleshooting activities not listed above?," suggesting that respondents adequately recognized their work as falling within the three broad areas of activity.

The way in which troubleshooting personnel applied specific tools to the above tasks is similarly ripe for expansiveness and introduces a new facet to the literature. For example, were the ERMS programs used only to ascertain the subscription status of a resource, or were more advanced features used to manage internal workflows? Were spreadsheets used to track issue details as they were reported or only to verify title lists of subscribed packages? Ethnographic study might be most productive, where researchers observe troubleshooting personnel to identify the tasks they perform and interview them to learn how they conceptualize and categorize those tasks. The three categories used here can be further explored with greater confidence if they align with mental models generally in place.

\section{Q3. What staffing arrangements support libraries' troubleshooting activities?}

The staffing of troubleshooting serves as an important counterpart to the tools used. A first consideration in this area is the number of library employees, and at what classification levels, have troubleshooting responsibilities. Libraries varied here considerably, with one to four individuals in this sample supporting a given library's troubleshooting. Almost all libraries had at least one paraprofessional position and at least one faculty position involved in troubleshooting, which reflects the importance that libraries place on this area of activity. A second consideration regarding staffing is the time that personnel dedicate to troubleshooting at each library. This was another area with considerable variation among libraries, with times ranging from 10 to 32 hours per week. Recall that except for the few that track these activities in detail, troubleshooting times should be considered very rough estimates. However, the general balance of time across staff 
levels may be more reliable: As might be expected, paraprofessionals dedicated much more time to troubleshooting, suggesting that faculty filled an oversight function. In this survey, it was impossible to include questions that would explore in depth the reasons behind the particular staffing choices. Focus groups, ethnographic observation, or open-ended questions would be useful for a more nuanced understanding of the circumstances that led to organizational arrangements around troubleshooting.

Two caveats with implications for future research should be highlighted. First, this study conflated one position classified as "professional" level into the "faculty" category for convenience. Little is known about the degree to which libraries employ non-faculty professionals to manage e-resources in general and troubleshooting in particular. With the multitude of gradations among library faculty at different institutions (tenure designation, differences in tenure process compared to other faculty at the same institution, participation in shared governance, etc.), the value of a professional-faculty distinction may be questionable. Second, organizational change is rampant. At the author's own institution, since the survey's distribution last year, the department where troubleshooting is housed has had two units combined into it, the individual with the highest percentage of troubleshooting responsibility left the institution, that position was split into one with dual reporting with resource sharing, and an additional faculty position was created and filled. Any study of staffing trends must not assume a static organizational foundation.

\section{Conclusion}

This study reveals contradictions in how libraries apply technological tools to the work of troubleshooting. Libraries of a similar size use many tools or only a few, but a few tools (notably Microsoft Outlook) are used by all. Libraries participate in the same general troubleshooting 
activities but have different priorities in deploying tools and personnel to the particular tasks of those respective areas. Libraries dedicate several positions or just a few to troubleshooting, many personnel-hours or just a few, but the costs allocated to the personnel and their tools are consequential in each case. Carrying out and categorizing troubleshooting activities are both complex undertakings, so perhaps the apparent commonalities among institutions are more an effect of the study's oversimplification than of true similarities.

Much more research on e-resource troubleshooting is recommended both to shape a theoretical foundation that aligns with practice and to provide an open body of knowledge for libraries to draw upon in choosing and using tools. In particular, libraries would benefit from systemized knowledge of practices related to these aspects of troubleshooting:

- factors that motivate personnel to seek to replace tools currently used in troubleshooting;

- the process of selecting technological tools for troubleshooting;

- activity areas within troubleshooting, their relative importance and time required, and the expertise or training necessary to handle each activity; and

- the motivations and relative success of the various organizational options for staffing troubleshooting.

Another article by this author uses data from this same survey to gauge the satisfaction of troubleshooting personnel with the tools they use. Such research can inform librarians' decisionmaking by identifying the factors correlated with satisfaction, thus helping libraries learn from the experience of others. In all of these areas of focus, studies with larger samples will of course have greater predictive ability.

Finally, the author recognizes that troubleshooting represents one small area within e-resource management. Maintaining access is intricately linked to staff training, institutional memory, 
license agreements, price models, invoicing practices, vendor negotiations, and many other activities. A unified "theory of everything," such as those attempted by the ERMI Report authors or the TERMS editors, would contextualize troubleshooting and its tools into this larger group of practices, which have their corresponding literatures and communities for sharing ideas.

Ultimately, this work can allow librarians to be efficient in allocating time and resources to meet the needs of their users. 


\section{References}

Borchert, C. A. (2006). Untangling the jungle of e-journal access issues using CRM software. Library Collections, Acquisitions, \& Technical Services, 30, 224-237. http://doi.org/10.1016/j.lcats.2006.10.002

Browning, S. (2015). Data, data, everywhere, nor any time to think: DIY analysis of e-resource access problems. Journal of Electronic Resources Librarianship, 27(1), 26-34. http://doi.org/10.1080/1941126X.2015.999521

Carter, S., \& Traill, S. (2017). Essential skills and knowledge for troubleshooting e-resources access issues in a web-scale discovery environment. Journal of Electronic Resources Librarianship, 29(1), 1-15. http://doi.org/10.1080/1941126X.2017.1270096

Emery, J., \& Stone, G. (Eds.). (n.d.). TERMS: Techniques for Electronic Resource Management. Retrieved March 20, 2017, from https://library.hud.ac.uk/blogs/terms/

Ennis, L. A., \& Tims, R. S. (2012). Help Central: Creating a help desk \& knowledge portal in SharePoint. Computers in Libraries, 32(2), 6-10.

Finch, M. (2014). Using Zapier with Trello for electronic resources troubleshooting workflow. Code4Lib Journal, (26). Retrieved from http://journal.code4lib.org/articles/10034

Jewell, T. D., Anderson, I., Chandler, A., Farb, S. E., Parker, K., Riggio, A., \& Robertson, N. D. M. (2004). Electronic resource management: Report of the DLF ERM Initiative. Washington, D.C. Retrieved from http://old.diglib.org/pubs/dlf102

National Center for Educational Statistics. (2013). Compare academic libraries. Retrieved from https://nces.ed.gov/surveys/libraries/Compare/Default.aspx

Pan, D., Bradbeer, G., \& Jurries, E. (2011). From communication to collaboration: Blogging to troubleshoot e-resources. The Electronic Library, 29(3), 344-353. 
http://doi.org/10.1108/02640471111141089

Rathmel, A., Mobley, L., Pennington, B., \& Chandler, A. (2015). Tools, techniques, and training: Results of an e-resources troubleshooting survey. Journal of Electronic Resources Librarianship, 27(2), 88-107. http://doi.org/10.1080/1941126X.2015.1029398

Resnick, T., \& Clark, D. T. (2009). Evolution of electronic resources support: Is virtual reference the answer? Library Hi Tech, 27(3), 357-371. http://doi.org/10.1108/07378830910988496

Rupp, N., \& Mobley, L. (2007). Use of technology in managing electronic resource workflow. Against the Grain, 19(5), 18, 20, 22. Retrieved from http://docs.lib.purdue.edu/cgi/viewcontent.cgi? article=5273\&context=atg

Samples, J., \& Healy, C. (2014). Making it look easy: Maintaining the magic of access. Serials Review, 40(2), 105-117. http://doi.org/10.1080/00987913.2014.929483

Walters, W. H. (2016). Faculty status of librarians at U.S. research universities. The Journal of Academic Librarianship, 42(2), 161-171. http://doi.org/10.1016/j.acalib.2015.11.002

Wilson, K. (2011). Beyond library software: New tools for electronic resources management. Serials Review, 37(4), 294-304. http://doi.org/10.1016/j.serrev.2011.09.010 


\section{Appendix: Text of survey instrument}

Troubleshooting tools

Q1 This survey of Utah State University's designated peer institutions focuses on the factors considered when selecting and using software tools for electronic-resource troubleshooting. Your responses to this short survey will fill a gap in the literature and provide librarians empirical support when adopting such tools in the future. The survey should take no longer than 15 minutes to complete. While your participation is of course voluntary, it is greatly appreciated.

If you have any questions or comments, please contact Robert Heaton, Utah State University's Electronic Collections Librarian, at 435-797-8042 or robert.heaton@usu.edu.

Q2 For the purposes of this study, troubleshooting staff includes any positions specifically designated as having e-resource troubleshooting duties, including part-time positions or positions only partially dedicated to troubleshooting. In general, these will be the individuals that receive issue reports from users and other library staff.

Q3 Enter the following information for each unique position among your troubleshooting staff. Job title

Department the position reports to

Job level (e.g., faculty, professional, paraprofessional)

Hours worked per week

Average hours dedicated to troubleshooting per week

Number of individuals filling this exact position

Q4 Enter the following information for each unique position among your troubleshooting staff.

Job title

Department the position reports to

Job level (e.g., faculty, professional, paraprofessional)

Hours worked per week

Average hours dedicated to troubleshooting per week

Number of individuals filling this exact position

Q5 Enter the following information for each unique position among your troubleshooting staff. Job title

Department the position reports to

Job level (e.g., faculty, professional, paraprofessional)

Hours worked per week

Average hours dedicated to troubleshooting per week

Number of individuals filling this exact position 
Q6 Enter the following information for each unique position among your troubleshooting staff. Job title

Department the position reports to

Job level (e.g., faculty, professional, paraprofessional)

Hours worked per week

Average hours dedicated to troubleshooting per week

Number of individuals filling this exact position

Q7 Note any explanatory information that may provide necessary context for understanding the above responses.

Q8 Which of the following tools are used directly in support of troubleshooting? (Select all that apply and type the name of each specific tool used. Note: The programs listed are given as illustrations only. Please select the category that applies to your specific use of the program rather than adhering to these somewhat arbitrary examples.)

An electronic resources management system (ERMS) (e.g., Alma, Sierra ERM, CORAL, WMS)

A subscription-manager admin tool (e.g., EBSCO Subscription Services, CoxNet)

An email program (e.g., Outlook, Gmail)

A chat program (e.g., LibChat, Slack, Google Hangouts, Skype)

$\square$ A survey platform (e.g., Google Forms, Qualtrics, SurveyMonkey)

A customer-relations-management tool or ticket tracker (e.g., LibAnswers, Bugzilla, JIRA, Groove, Footprints)

$\square$ A task- or project-management platform (e.g., Asana, Trello, Outlook, Podio)

A calendar program (e.g., Outlook, Google Calendar)

$\square$ A database program (e.g., Access, FileMaker Pro)

口 A spreadsheet program (e.g., Excel, Google Sheets)

$\square$ A file-storage or -sharing program (e.g., Dropbox, Box, Google Drive)

An intranet platform (e.g., Basecamp, SharePoint, Drupal)

口 A blogging or content-management platform (e.g., WordPress, Drupal)

A screenshot or screen-sharing program (e.g., Screencast-O-Matic, Join.me, Jing)

Q9 Does your institution use troubleshooting tools not listed above? Please list them below. 
Q10 For how many years has each selected tool been in use for troubleshooting purposes at your library?

\begin{tabular}{|c|c|c|c|}
\hline & under 1 year & $1-2$ years & 3 or more years \\
\hline $\begin{array}{c}\text { [text entered in Q8] } \\
\text { (ERMS) }\end{array}$ & O & $\mathrm{O}$ & 0 \\
\hline $\begin{array}{l}\text { [text entered in Q8] } \\
\text { (subscription } \\
\text { manager) }\end{array}$ & 0 & 0 & 0 \\
\hline $\begin{array}{l}\text { [text entered in Q8] } \\
\text { (email program) }\end{array}$ & 0 & 0 & 0 \\
\hline $\begin{array}{l}\text { [text entered in Q8] } \\
\text { (chat program) }\end{array}$ & O & $\mathrm{O}$ & $\mathrm{O}$ \\
\hline $\begin{array}{c}\text { [text entered in Q8] } \\
\text { (survey platform) }\end{array}$ & 0 & $\mathrm{O}$ & 0 \\
\hline $\begin{array}{l}\text { [text entered in Q8] } \\
\text { (CRM/ticket tracker) }\end{array}$ & 0 & 0 & 0 \\
\hline $\begin{array}{l}\text { [text entered in Q8] } \\
\text { (task-/project- } \\
\text { management } \\
\text { platform) }\end{array}$ & O & O & $\mathrm{O}$ \\
\hline $\begin{array}{c}\text { [text entered in Q8] } \\
\text { (calendar program) }\end{array}$ & O & O & 0 \\
\hline $\begin{array}{l}\text { [text entered in Q8] } \\
\text { (database program) }\end{array}$ & O & 0 & 0 \\
\hline $\begin{array}{l}\text { [text entered in Q8] } \\
\text { (spreadsheet } \\
\text { program) }\end{array}$ & O & $\mathrm{O}$ & O \\
\hline $\begin{array}{c}\text { [text entered in Q8] } \\
\text { (file-storage/-sharing } \\
\text { tool) }\end{array}$ & 0 & 0 & 0 \\
\hline $\begin{array}{l}\text { [text entered in Q8] } \\
\text { (intranet platform) }\end{array}$ & O & $\mathrm{O}$ & $\mathrm{O}$ \\
\hline $\begin{array}{l}\text { [text entered in Q8] } \\
\text { (blogging/content- } \\
\text { management } \\
\text { platform) }\end{array}$ & O & $\mathrm{O}$ & $\mathrm{O}$ \\
\hline $\begin{array}{c}\text { [text entered in Q8] } \\
\text { (screenshot/screen- } \\
\text { sharing program) }\end{array}$ & 0 & 0 & 0 \\
\hline
\end{tabular}


Q11 What troubleshooting activities are accomplished using each tool?

\begin{tabular}{|c|c|c|c|}
\hline & $\begin{array}{l}\text { Gather information } \\
\text { to understand and } \\
\text { replicate the issue } \\
\text { (e.g., receive issue } \\
\text { reports from users or } \\
\text { librarians, review } \\
\text { past issues for } \\
\text { relevant clues, } \\
\text { replicate the issue on } \\
\text { staff computers) }\end{array}$ & $\begin{array}{l}\text { Communicate issue } \\
\text { status to users (e.g., } \\
\text { general notices on a } \\
\text { blog or website, } \\
\text { direct email to the } \\
\text { individual who } \\
\text { reported an issue, in- } \\
\text { house memos to } \\
\text { prepare staff for user } \\
\text { complaints) }\end{array}$ & $\begin{array}{l}\text { Coordinate tasks } \\
\text { among } \\
\text { troubleshooting team } \\
\text { and other library staff } \\
\text { (e.g., assign tasks to } \\
\text { troubleshooting staff, } \\
\text { schedule tasks for } \\
\text { later follow-up, view } \\
\text { task status in real } \\
\text { time) }\end{array}$ \\
\hline $\begin{array}{l}\text { [text entered in Q8] } \\
\text { (ERMS) }\end{array}$ & $\square$ & $\square$ & $\square$ \\
\hline $\begin{array}{c}\text { [text entered in Q8] } \\
\text { (subscription } \\
\text { manager) }\end{array}$ & $\square$ & $\square$ & $\square$ \\
\hline $\begin{array}{l}\text { [text entered in Q8] } \\
\text { (email program) }\end{array}$ & $\square$ & $\square$ & $\square$ \\
\hline $\begin{array}{l}\text { [text entered in Q8] } \\
\quad(\text { chat program })\end{array}$ & 口 & $\square$ & $\square$ \\
\hline $\begin{array}{c}\text { [text entered in Q8] } \\
\text { (survey platform) }\end{array}$ & $\square$ & $\square$ & $\square$ \\
\hline $\begin{array}{c}\text { [text entered in Q8] } \\
\text { (CRM/ticket tracker) }\end{array}$ & $\square$ & $\square$ & $\square$ \\
\hline $\begin{array}{l}\text { [text entered in Q8] } \\
\text { (task-/project- } \\
\text { management } \\
\text { platform) }\end{array}$ & $\square$ & $\square$ & $\square$ \\
\hline $\begin{array}{l}\text { [text entered in Q8] } \\
\text { (calendar program) }\end{array}$ & $\square$ & $\square$ & $\square$ \\
\hline $\begin{array}{l}\text { [text entered in Q8] } \\
\text { (database program) }\end{array}$ & $\square$ & 口 & 口 \\
\hline $\begin{array}{l}\text { [text entered in Q8] } \\
\text { (spreadsheet } \\
\text { program) }\end{array}$ & $\square$ & $\square$ & $\square$ \\
\hline $\begin{array}{c}\text { [text entered in Q8] } \\
\text { (file-storage/-sharing } \\
\text { tool) }\end{array}$ & $\square$ & $\square$ & 口 \\
\hline $\begin{array}{l}\text { [text entered in Q8] } \\
\text { (intranet platform) }\end{array}$ & $\square$ & $\square$ & $\square$ \\
\hline $\begin{array}{l}\text { [text entered in Q8] } \\
\text { (blogging/content- }\end{array}$ & ם & 口 & $\square$ \\
\hline
\end{tabular}




\begin{tabular}{|c|c|c|c|}
\hline $\begin{array}{c}\text { management } \\
\text { platform })\end{array}$ & & \\
[text entered in Q8] & & $\square$ & $\square$ \\
(screenshot/screen- & $\square$ & $\square$ & \\
sharing program) & $\square$ & & \\
\hline
\end{tabular}

Q12 Does your institution engage in troubleshooting activities not listed above? Please list them below.

Q13 Please rate the satisfaction level of troubleshooting staff with the performance of each tool in the activities you selected.

Q14 How satisfied are troubleshooting staff with each tool's performance in the following activity: Gather information to understand and replicate the issue (e.g., receive issue reports from users or librarians, review past issues for relevant clues, replicate the issue on staff computers)?

\begin{tabular}{|c|c|c|c|c|c|}
\hline & $\begin{array}{l}\text { Extremely } \\
\text { satisfied }\end{array}$ & $\begin{array}{l}\text { Somewhat } \\
\text { satisfied }\end{array}$ & $\begin{array}{c}\text { Neither } \\
\text { satisfied nor } \\
\text { dissatisfied }\end{array}$ & $\begin{array}{l}\text { Somewhat } \\
\text { dissatisfied }\end{array}$ & $\begin{array}{l}\text { Extremely } \\
\text { dissatisfied }\end{array}$ \\
\hline $\begin{array}{l}\text { [text entered in Q8 if } \\
\text { first option in Q11 } \\
\text { was selected] } \\
(\text { ERMS })\end{array}$ & 0 & 0 & 0 & 0 & 0 \\
\hline $\begin{array}{c}\text { [text entered in Q8 if } \\
\text { first option in Q11 } \\
\text { was selected] } \\
\text { (subscription } \\
\text { manager) }\end{array}$ & 0 & 0 & 0 & 0 & 0 \\
\hline $\begin{array}{c}\text { [text entered in Q8 if } \\
\text { first option in Q11 } \\
\text { was selected] (email } \\
\text { program) }\end{array}$ & 0 & 0 & 0 & 0 & 0 \\
\hline $\begin{array}{l}\text { [text entered in Q8 if } \\
\text { first option in Q11 } \\
\text { was selected] (chat } \\
\text { program) }\end{array}$ & 0 & 0 & 0 & 0 & 0 \\
\hline $\begin{array}{l}\text { [text entered in Q8 if } \\
\text { first option in Q11 } \\
\text { was selected] (survey } \\
\text { platform) }\end{array}$ & 0 & 0 & 0 & 0 & 0 \\
\hline $\begin{array}{l}\text { [text entered in Q8 if } \\
\text { first option in Q11 }\end{array}$ & 0 & 0 & 0 & 0 & 0 \\
\hline
\end{tabular}




\begin{tabular}{|c|c|c|c|c|c|}
\hline $\begin{array}{c}\text { was selected] } \\
\text { (CRM/ticket tracker) } \\
\text { [text entered in Q8 if } \\
\text { first option in Q11 } \\
\text { was selected] (task- } \\
\text { /project-management } \\
\text { platform) } \\
\text { [text entered in Q8 if } \\
\text { first option in Q11 } \\
\text { was selected] } \\
\text { (calendar program) } \\
\text { [text entered in Q8 if } \\
\text { first option in Q11 } \\
\text { was selected] } \\
\text { (database program) } \\
\text { [text entered in Q8 if } \\
\text { first option in Q11 } \\
\text { was selected] } \\
\text { (spreadsheet } \\
\text { program) } \\
\text { [text entered in Q8 if } \\
\text { first option in Q11 } \\
\text { was selected] (file- } \\
\text { storage/-sharing tool) } \\
\text { [text entered in Q8 if } \\
\text { first option in Q11 } \\
\text { was selected] } \\
\text { (intranet platform) } \\
\text { [text entered in Q8 if } \\
\text { first option in Q11 } \\
\text { was selected] } \\
\text { (blogging/content- } \\
\text { management } \\
\text { platform) } \\
\text { [text entered in Q8 if } \\
\text { first option in Q11 } \\
\text { was selected] } \\
\text { (screenshot/screen- } \\
\text { sharing program) }\end{array}$ & 0 & 0 & 0 & 0 & 0 \\
\hline
\end{tabular}

Q15 How satisfied are troubleshooting staff with each tool's performance in the following activity: Communicate issue status to users (e.g., general notices on a blog or website, direct 
email to the individual who reported an issue, in-house memos to prepare staff for user complaints)?

\begin{tabular}{|c|c|c|c|c|c|}
\hline & $\begin{array}{l}\text { Extremely } \\
\text { satisfied }\end{array}$ & $\begin{array}{l}\text { Somewhat } \\
\text { satisfied }\end{array}$ & $\begin{array}{c}\text { Neither } \\
\text { satisfied nor } \\
\text { dissatisfied }\end{array}$ & $\begin{array}{l}\text { Somewhat } \\
\text { dissatisfied }\end{array}$ & $\begin{array}{l}\text { Extremely } \\
\text { dissatisfied }\end{array}$ \\
\hline $\begin{array}{c}\text { [text entered in Q8 if } \\
\text { second option in Q11 } \\
\text { was selected] (ERMS) }\end{array}$ & 0 & 0 & 0 & 0 & 0 \\
\hline $\begin{array}{c}\text { [text entered in Q8 if } \\
\text { second option in Q11 } \\
\text { was selected] } \\
\text { (subscription manager) }\end{array}$ & 0 & 0 & 0 & 0 & 0 \\
\hline $\begin{array}{c}\text { [text entered in Q8 if } \\
\text { second option in Q11 } \\
\text { was selected] (email } \\
\text { program) }\end{array}$ & 0 & 0 & 0 & 0 & 0 \\
\hline $\begin{array}{c}\text { [text entered in Q8 if } \\
\text { second option in Q11 } \\
\text { was selected] (chat } \\
\text { program) }\end{array}$ & 0 & 0 & 0 & 0 & 0 \\
\hline $\begin{array}{c}\text { [text entered in Q8 if } \\
\text { second option in Q11 } \\
\text { was selected] (survey } \\
\text { platform) }\end{array}$ & $\bigcirc$ & 0 & 0 & 0 & 0 \\
\hline $\begin{array}{c}\text { [text entered in Q8 if } \\
\text { second option in Q11 } \\
\text { was selected] } \\
\text { (CRM/ticket tracker) }\end{array}$ & 0 & 0 & 0 & 0 & O \\
\hline $\begin{array}{l}\text { [text entered in Q8 if } \\
\text { second option in Q11 } \\
\text { was selected] (task- } \\
\text { /project-management } \\
\text { platform) }\end{array}$ & 0 & 0 & 0 & 0 & 0 \\
\hline $\begin{array}{c}\text { [text entered in Q8 if } \\
\text { second option in Q11 } \\
\text { was selected] (calendar } \\
\text { program) }\end{array}$ & 0 & 0 & 0 & $\bigcirc$ & 0 \\
\hline $\begin{array}{c}\text { [text entered in Q8 if } \\
\text { second option in Q11 } \\
\text { was selected] (database } \\
\text { program) }\end{array}$ & 0 & 0 & 0 & 0 & O \\
\hline $\begin{array}{l}\text { [text entered in Q8 if } \\
\text { second option in Q11 }\end{array}$ & 0 & 0 & 0 & 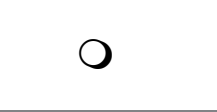 & 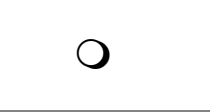 \\
\hline
\end{tabular}




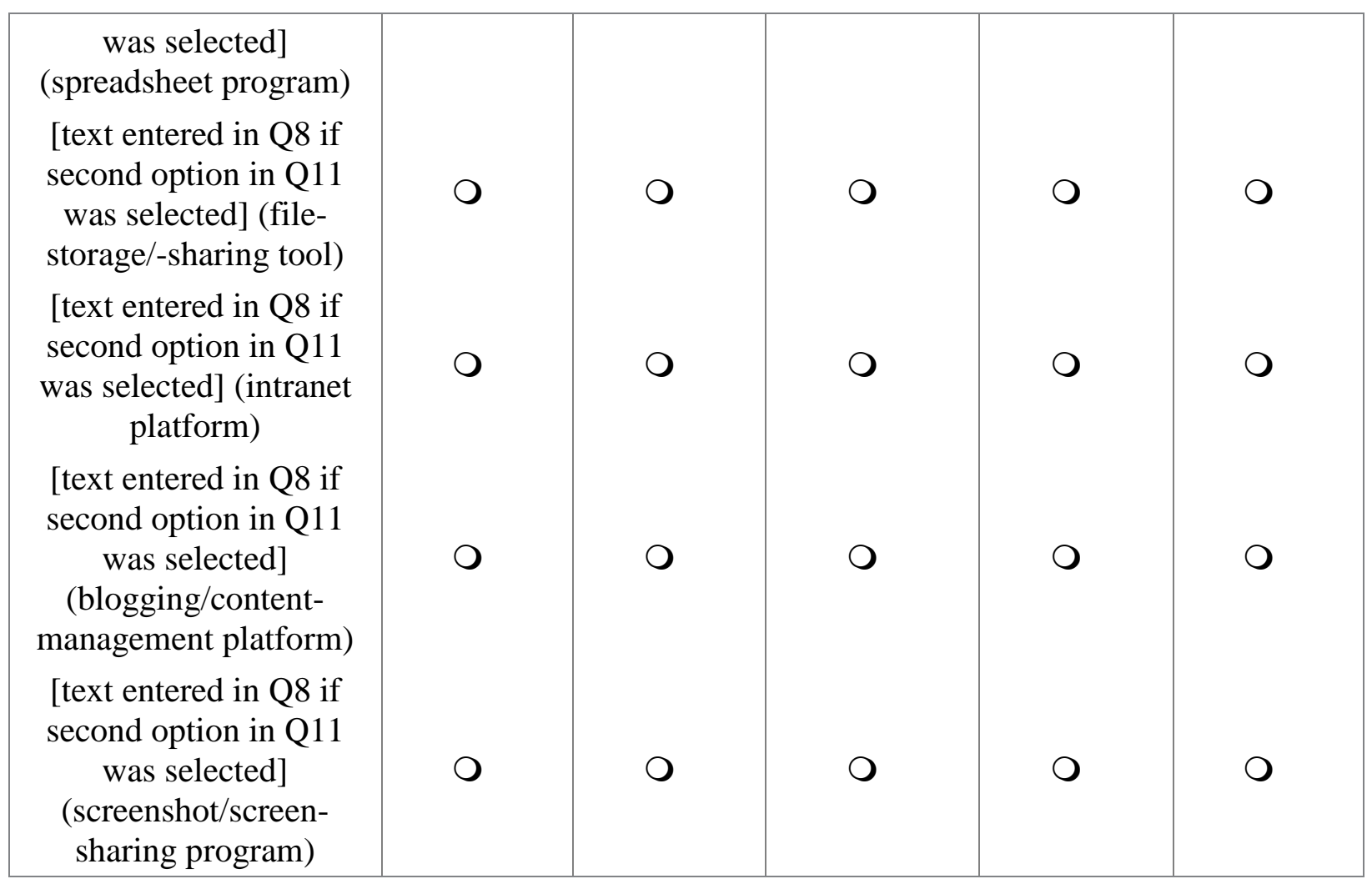

Q16 How satisfied are troubleshooting staff with each tool's performance in the following activity: Coordinate tasks among troubleshooting team and other library staff (e.g., assign tasks to troubleshooting staff, schedule tasks for later follow-up, view task status in real time)?

\begin{tabular}{|c|c|c|c|c|c|}
\hline & $\begin{array}{l}\text { Extremely } \\
\text { satisfied }\end{array}$ & $\begin{array}{l}\text { Somewhat } \\
\text { satisfied }\end{array}$ & $\begin{array}{c}\text { Neither } \\
\text { satisfied nor } \\
\text { dissatisfied }\end{array}$ & $\begin{array}{l}\text { Somewhat } \\
\text { dissatisfied }\end{array}$ & $\begin{array}{l}\text { Extremely } \\
\text { dissatisfied }\end{array}$ \\
\hline $\begin{array}{l}\text { [text entered in Q8 if third } \\
\text { option in Q11 was } \\
\text { selected] (ERMS) }\end{array}$ & 0 & 0 & 0 & 0 & 0 \\
\hline $\begin{array}{c}\text { [text entered in Q8 if third } \\
\text { option in Q11 was } \\
\text { selected] (subscription } \\
\text { manager) }\end{array}$ & 0 & 0 & 0 & 0 & 0 \\
\hline $\begin{array}{l}\text { [text entered in Q8 if third } \\
\text { option in Q11 was } \\
\text { selected] (email program) }\end{array}$ & 0 & 0 & 0 & 0 & 0 \\
\hline $\begin{array}{l}\text { [text entered in Q8 if third } \\
\text { option in Q11 was } \\
\text { selected] (chat program) }\end{array}$ & 0 & 0 & 0 & 0 & 0 \\
\hline
\end{tabular}




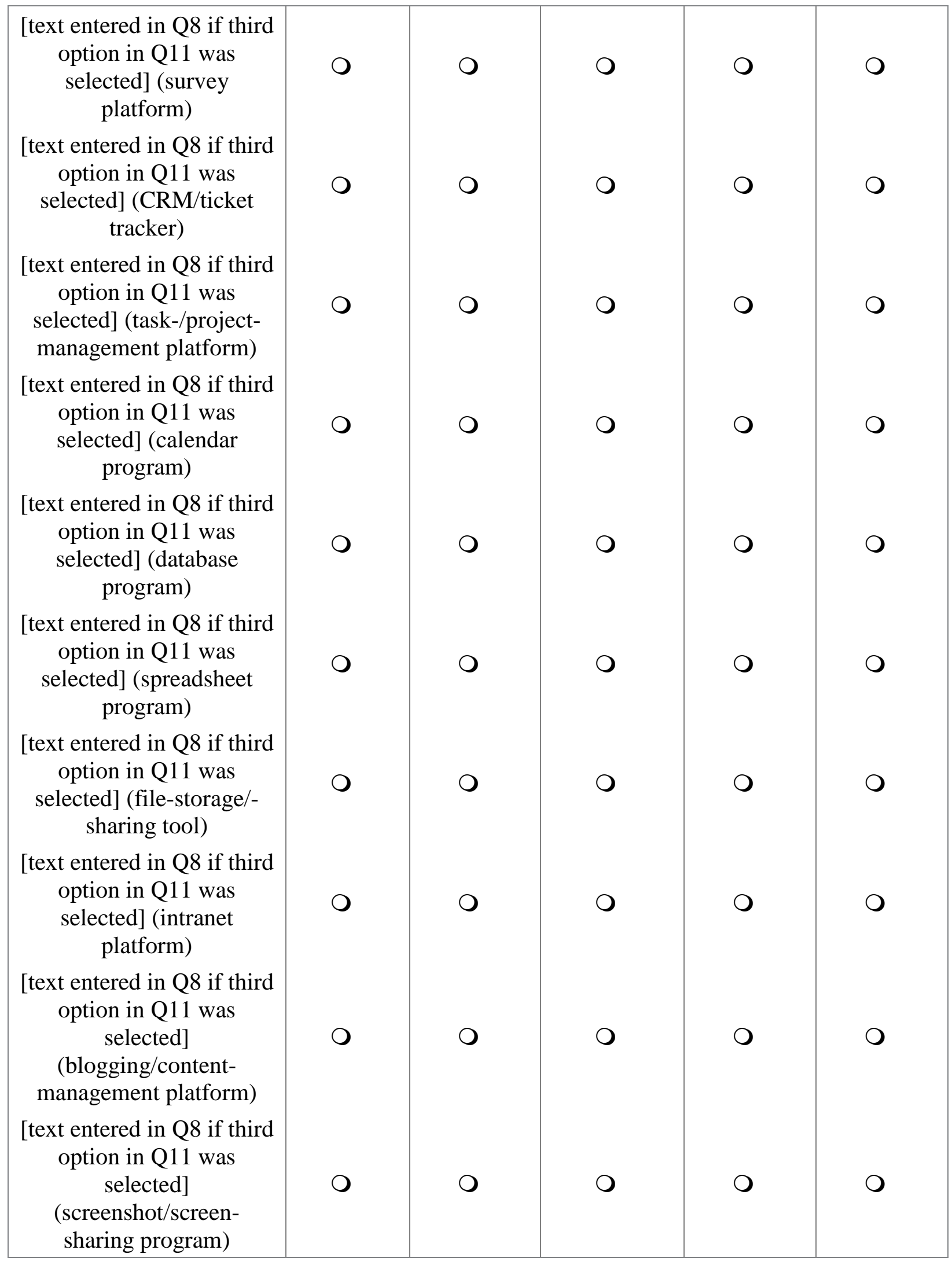


Q17 Which statements are true for each tool used in troubleshooting? (Select all that apply. Leave blank if unknown.)

\begin{tabular}{|c|c|c|c|c|}
\hline & $\begin{array}{l}\text { Troubleshooting } \\
\text { staff (and not } \\
\text { someone else) } \\
\text { selected the tool } \\
\text { for use in } \\
\text { troubleshooting }\end{array}$ & $\begin{array}{c}\text { The tool is used } \\
\text { for non- } \\
\text { troubleshooting } \\
\text { purposes by } \\
\text { other staff at the } \\
\text { library or } \\
\text { university }\end{array}$ & $\begin{array}{l}\text { Staff applied a } \\
\text { relatively } \\
\text { formal } \\
\text { evaluation or } \\
\text { comparison } \\
\text { process before } \\
\text { adopting the } \\
\text { tool }\end{array}$ & $\begin{array}{l}\text { Troubleshooting } \\
\text { staff are } \\
\text { relatively active } \\
\text { in seeking a } \\
\text { replacement for } \\
\text { this tool }\end{array}$ \\
\hline $\begin{array}{c}\text { [text entered in } \\
\text { Q8] (ERMS) }\end{array}$ & $\square$ & $\square$ & 口 & $\square$ \\
\hline $\begin{array}{l}\text { [text entered in } \\
\text { Q8] (subscription } \\
\text { manager) }\end{array}$ & $\square$ & $\square$ & 口 & $\square$ \\
\hline $\begin{array}{l}\text { [text entered in } \\
\text { Q8] (email } \\
\text { program) }\end{array}$ & 口 & $\square$ & 口 & $\square$ \\
\hline $\begin{array}{l}\text { [text entered in } \\
\text { Q8] (chat } \\
\text { program) }\end{array}$ & $\square$ & $\square$ & $\square$ & $\square$ \\
\hline $\begin{array}{c}\text { [text entered in } \\
\text { Q8] (survey } \\
\text { platform) }\end{array}$ & 口 & $\square$ & $\square$ & 口 \\
\hline $\begin{array}{c}\text { [text entered in } \\
\text { Q8] (CRM/ticket } \\
\text { tracker })\end{array}$ & 口 & 口 & 口 & $\square$ \\
\hline $\begin{array}{c}\text { [text entered in } \\
\text { Q8] (task-/project- } \\
\text { management } \\
\text { platform) }\end{array}$ & $\square$ & $\square$ & $\square$ & 口 \\
\hline $\begin{array}{c}\text { [text entered in } \\
\text { Q8] (calendar } \\
\text { program) }\end{array}$ & 口 & $\square$ & 口 & $\square$ \\
\hline $\begin{array}{c}\text { [text entered in } \\
\text { Q8] (database } \\
\text { program) }\end{array}$ & 口 & 口 & $\square$ & 口 \\
\hline $\begin{array}{c}\text { [text entered in } \\
\text { Q8] (spreadsheet } \\
\text { program) }\end{array}$ & $\square$ & $\square$ & 口 & $\square$ \\
\hline
\end{tabular}




\begin{tabular}{|c|c|c|c|c|}
\hline $\begin{array}{c}\text { [text entered in } \\
\text { Q8] (file-storage/- } \\
\text { sharing tool) }\end{array}$ & $\square$ & $\square$ & $\square$ & $\square$ \\
\hline $\begin{array}{l}\text { [text entered in } \\
\text { Q8] (intranet } \\
\text { platform) }\end{array}$ & $\square$ & $\square$ & $\square$ & $\square$ \\
\hline $\begin{array}{l}\text { [text entered in } \\
\text { Q8] } \\
\text { (blogging/content- } \\
\text { management } \\
\text { platform) }\end{array}$ & 口 & $\square$ & $\square$ & $\square$ \\
\hline $\begin{array}{c}\text { [text entered in } \\
\text { Q8] } \\
\text { (screenshot/screen- } \\
\text { sharing program) }\end{array}$ & 口 & $\square$ & $\square$ & $\square$ \\
\hline
\end{tabular}

Q18 Enter the following information for yourself.

Your job title

Years in your current position

Years in an electronic-resources role at your current library

Your institution

Q19 If you would like to share any additional details about your library's staffing or tools relevant to e-resource troubleshooting or offer any feedback on this survey, please do so here. 